\title{
Review Article \\ Beneficial Effects of Dietary Nitrate on Endothelial Function and Blood Pressure Levels
}

\author{
Jenifer d'El-Rei, Ana Rosa Cunha, Michelle Trindade, and Mario Fritsch Neves \\ Department of Clinical Medicine, State University of Rio de Janeiro, 20551-030 Rio de Janeiro, RJ, Brazil \\ Correspondence should be addressed to Jenifer d'El-Rei; jeniferdelrei@gmail.com
}

Received 30 December 2015; Revised 2 February 2016; Accepted 22 February 2016

Academic Editor: Claudio Borghi

Copyright (C) 2016 Jenifer d'El-Rei et al. This is an open access article distributed under the Creative Commons Attribution License, which permits unrestricted use, distribution, and reproduction in any medium, provided the original work is properly cited.

Poor eating habits may represent cardiovascular risk factors since high intake of fat and saturated fatty acids contributes to dyslipidemia, obesity, diabetes mellitus, and hypertension. Thus, nutritional interventions are recognized as important strategies for primary prevention of hypertension and as adjuvants to pharmacological therapies to reduce cardiovascular risk. The DASH (Dietary Approach to Stop Hypertension) plan is one of the most effective strategies for the prevention and nonpharmacological management of hypertension. The beneficial effects of DASH diet on blood pressure might be related to the high inorganic nitrate content of some food products included in this meal plan. The beetroot and other food plants considered as nitrate sources account for approximately $60-80 \%$ of the daily nitrate exposure in the western population. The increased levels of nitrite by nitrate intake seem to have beneficial effects in many of the physiological and clinical settings. Several clinical trials are being conducted to determine the broad therapeutic potential of increasing the bioavailability of nitrite in human health and disease, including studies related to vascular aging. In conclusion, the dietary inorganic nitrate seems to represent a promising complementary therapy to support hypertension treatment with benefits for cardiovascular health.

\section{Introduction}

Hypertension is a multifactorial condition characterized by high and sustained levels of blood pressure (BP). It is the most common condition in primary care and often associated with functional and/or structural changes in target organs and metabolic disorders, increasing the risk of fatal and nonfatal cardiovascular events $[1,2]$. Among the risk factors for mortality from cardiovascular disease (CVD), hypertension explains $40 \%$ and $25 \%$ of deaths from stroke and coronary artery disease (CAD), respectively [3].

$\mathrm{BP}$ is a biological and dynamic variable, dependent on many factors. Endothelial cells of the vascular system are responsible for many biochemical reactions that maintain vascular homeostasis and consequently the BP levels [4]. Endothelium modulates vascular tone, not only by producing vasodilator substances but also by releasing vasoconstrictive substances through prostanoid of endothelin generation, as well as through conversion of angiotensin I (AI) in angiotensin II (AII) on the endothelial surface. These vasoconstrictor agents not only act mainly locally but also present some systemic effects, playing an important role in regulating the vascular function and remodeling the arterial wall. In healthy individuals, there is a balance among these substances, tending to vasodilatation when endothelial function is normal [5].

\section{Nitric Oxide (NO), Endothelial Dysfunction, and Metabolic Syndrome}

Changes in endothelial function precede morphological changes of blood vessels and contribute to the development of clinical complications of cardiovascular diseases. Thus, the beginning and the clinical course of adverse cardiovascular events depend directly on changes in vascular biology. Lately, it became clear that the endothelium is responsible for promoting vascular homeostasis [5].

The limited NO bioavailability is the main mechanism involved in endothelial dysfunction, which is crucial for the development of CVD [6]. In fact, endothelial dysfunction in peripheral and coronary vessels is an independent predictor of cardiovascular events and represents an early stage of 
CAD [7]. As endothelial dysfunction is reversible, early detection and intervention could have critical therapeutic and prognostic implications for patients with risk for, or even with established, CVD $[7,8]$. Therefore, an improvement in the NO bioavailability can have a major effect on endothelial function and, consequently, on CVD prevention and treatment $[9,10]$.

Metabolic syndrome can be considered a clinical and biochemical expression of insulin resistance, representing a clustering of central obesity, hypertension, hyperglycemia, and dyslipidemia $[19,20]$. Recently, experimental models and clinical studies demonstrated that reductions in the NO bioavailability play a central role in the pathophysiology of metabolic dysfunction. Endothelial nitric oxide synthase(eNOS-) deficient mice were able to develop high BP and metabolic dysfunction, and both might be the result of insulin resistance [21, 22]. In the same experimental model, several features of metabolic syndrome could be reversed by dietary supplementation with sodium nitrate. The amount of dietary nitrate used for this effect was comparable to those derived from eNOS under normal conditions, which corresponds to a rich intake of vegetables for humans. Besides, dietary nitrate was able to increase tissue and plasma levels of bioactive nitrogen oxides. Lastly, chronic nitrate supplementation prevented the prediabetic phenotype in these animals by reducing visceral fat accumulation and circulating levels of triglycerides [23]. In humans, eNOS polymorphisms have been associated with insulin resistance, type 2 diabetes mellitus, and metabolic syndrome [21]. Furthermore, recent evidences have shown that obese subjects present a reduced ability to produce NO $[10,24]$. Therefore, the dietary nitrate has been widely studied in clinical trials as an alternative form of the classical pathway of L-arginine to NO production.

\section{Sources and Beneficial Effects of Dietary Nitrate}

Poor eating habits may be considered as risk factors for CVD. In fact, high intake of foods rich in cholesterol, lipids, and saturated fatty acids and low consumption of fiber sources are related to dyslipidemia, obesity, diabetes mellitus, and hypertension [25]. Thus, nutritional interventions associated with changes in lifestyle are recognized as important strategies for primary prevention of hypertension and are auxiliary to pharmacological therapies to reduce cardiovascular risk [26].

Epidemiological evidences suggest that vegetable consumption reduces BP and risk of CVD [27-29]. DASH (Dietary Approach to Stop Hypertension) eating plan is one of the major effective strategies for prevention and nonpharmacological management of hypertension [30]. This eating proposal highlights the importance of increasing fruit and vegetables intake [31], and recent research suggests that the beneficial effects of DASH plan on BP are related to high inorganic nitrate content of food included in this eating plan (e.g., green leaves and root vegetables) [32, 33].

Beetroots, lettuce, chard, arugula, and spinach are the vegetables containing the highest amount of nitrate, $>250 \mathrm{mg}$ nitrate/100 g [32]. Table 1 shows the vegetables
TABLE 1: Vegetables grouping according to the nitrate concentration [11].

\begin{tabular}{lc}
\hline $\begin{array}{l}\text { Nitrate content } \\
(\mathrm{mg} / 100 \mathrm{~g} \text { of fresh food })\end{array}$ & Vegetables \\
\hline Very low, $<20 \mathrm{mg}$ & $\begin{array}{c}\text { Asparagus, garlic, onion, green bean, } \\
\text { pepper, potato, sweet potato, tomato, } \\
\text { and watermelon }\end{array}$ \\
Low, $20-<50 \mathrm{mg}$ & $\begin{array}{c}\text { Broccoli, carrot, cauliflower, and } \\
\text { chicory }\end{array}$ \\
Regular, 50-<100 mg & $\begin{array}{c}\text { Cabbage, turnip, and dill } \\
\text { High, } 100-<250 \mathrm{mg}\end{array}$ \\
Very high, $>250 \mathrm{mg}$ & $\begin{array}{c}\text { Endive, sweet leaf, parsley, and leek } \\
\text { Celery, chard, lettuce, beetroot, } \\
\text { spinach, arugula, and watercress }\end{array}$ \\
\hline
\end{tabular}

classification according to the nitrate content. Beetroot is a vegetable, particularly rich in inorganic nitrate, which contains an average of $2056 \mathrm{mg}$ of nitrate in a traditional cultivation. There are some studies using beetroot to test the effects of inorganic nitrate intake on $\mathrm{BP}$ [18].

Nitrate $\left(\mathrm{NO}_{3}{ }^{-}\right)$and nitrite $\left(\mathrm{NO}_{2}{ }^{-}\right)$, present in beetroot and in other food sources, were recently related to cardiovascular benefits. However, they were previously considered as toxic compounds due to the development of malignancies such as gastric cancer. Therefore, strict rules regarding these inorganic anions are regulated in food and in drinking water [34].

Beetroot and other vegetables sources of nitrate contain approximately $60-80 \%$ of the daily nitrate intake in the western population [32]. Nitrate content in vegetables may be influenced by factors related to the plant itself, such as variety, species, and maturity, and to the environment, such as temperature, light intensity, lack of some nutrients, and fertilizer use [11].

International organizations indicate that the consumption of dietary nitrate is about 31 to $185 \mathrm{mg}$ /day in Europe and 40 to $100 \mathrm{mg} /$ day in USA [35], and the oral bioavailability of dietary nitrate is $100 \%$ [36]. In 1962, World Health Organization (WHO) set an upper limit of nitrate consumption in food. An acceptable daily intake is $3.7 \mathrm{mg} \mathrm{NO}_{3}{ }^{-}$/body weight $(\mathrm{kg})$, which is the same value adopted by the European Authority for Food Safety. This amount is equivalent to $300 \mathrm{mg} /$ day for an adult weighing $80 \mathrm{~kg}$ [37]. However, there is no evidence that nitrate intake is carcinogenic in humans. Instead, epidemiological evidence indicates that consumption of vegetables reduces risk of cancer [38].

After intake, dietary nitrate quickly increases in plasma, in about 30 minutes, reaching its peak in 90 minutes. In contrast, nitrite levels are considerably slower in circulation, reaching their peak in 2.5 to 3 hours. Most of inorganic nitrate, about $75 \%$ of absorbed nitrate, is excreted in urine and $25 \%$ of plasma nitrate is excreted in saliva $[18,39]$. The exact mechanism of salivary concentration is unknown. As a result, there is supply of substrate for nitrate reductase expressed by bacteria that colonize the dorsal surface of the tongue, resulting in reduction of nitrate to nitrite. After nitrite 
is then swallowed, the stomach and the acid environment reduce it to NO. The remaining nitrite is reabsorbed again by the vascular flow [40]. NO and nitrite continue through the systemic circulation, and the remaining nitrite is reduced to $\mathrm{NO}$ in high resistance vessels, promoting vasodilatation and consequently lowering BP [18] (Figure 1). Both $\mathrm{NO}_{3}{ }^{-}$ and $\mathrm{NO}_{2}{ }^{-}$from diet and via L-arginine participate in the NO synthesis [41]. Lately, there is a growing body of interest on the role of these two anions in biological function. The improvement in vascular dysfunction and in BP levels after dietary nitrate seems to be mediated by effects on oxidative stress and inflammation $[42,43]$.

\section{Effects of Dietary Nitrate on Blood Pressure}

After an acute intake of beetroot juice $(500 \mathrm{~mL})$, it is possible to observe reduction of $10 \mathrm{mmHg}$ in systolic BP (after $2.5 \mathrm{~h}$ ) and reduction of $8 \mathrm{mmHg}$ in diastolic $\mathrm{BP}$ (after $3 \mathrm{~h}$ ) in healthy individuals. The decrease in BP was sustained after $24 \mathrm{~h}$ of juice intake. The highest reduction in $\mathrm{BP}$ is correlated to the peak in plasma nitrite [18].

Liu et al. evaluated the effects of a meal rich in nitrate (based on spinach consumption) on BP and arterial stiffness in healthy individuals. Two hours after a nitrate-rich meal consumption (220 mg nitrate), there was a larger artery elasticity index, lower pulse pressure, and lower systolic BP compared to the values after a standard meal, low in nitrate [44].

Recent experimental studies $[23,45,46]$ and clinical trials have shown that nitrate dietary intakes from beetroot juice $[18,47]$, beet-enriched bread [48], or inorganic nitrate supplements [49] have a protective effect against CVD because of reducing $\mathrm{BP}$, platelet aggregation inhibition, and prevention of endothelial dysfunction.

Recently, Bondonno et al. have shown that chronic ingestion of beetroot juice (one week, $420 \mathrm{mg}$ nitrate/day) did not improve the BP control in treated hypertensive patients [13]. In another study with overweight elderly subjects, Jajja et al. showed reduction of $7 \mathrm{mmHg}$ in systolic BP, after three weeks of beetroot juice intake ( $350 \mathrm{mg}$ nitrate/day). However, when BP was evaluated for 24 hours by ambulatory blood pressure monitoring (ABPM), no significant changes were shown in BP levels [14]. Table 2 shows some clinical trials that evaluated the effects of nitrate intake on $\mathrm{BP}$ and vascular function. In fact, there is no consensus about the effects of dietary inorganic nitrates on BP and endothelial function, and their effects on cardiovascular health, despite studies with positive results.

Since the initial investigations in healthy volunteers, studies using inorganic nitrate and formulations with nitrate salt showed promising results reducing BP, with nitrate doses ranging from 155 to $1484 \mathrm{mg} /$ day, between 1 and 15 days, with reductions of $4 \mathrm{mmHg}$ in systolic $\mathrm{BP}$ and of $1 \mathrm{mmHg}$ in diastolic BP $[33,50]$. In hypertensive patients, systolic $\mathrm{BP}$ remained significantly reduced in approximately $8 \mathrm{mmHg}$ over 24 hours after the intervention, which is similar to the reduction provided by drug therapy $(9 \mathrm{mmHg})$. This is important because the ingestion of dietary nitrate in a single

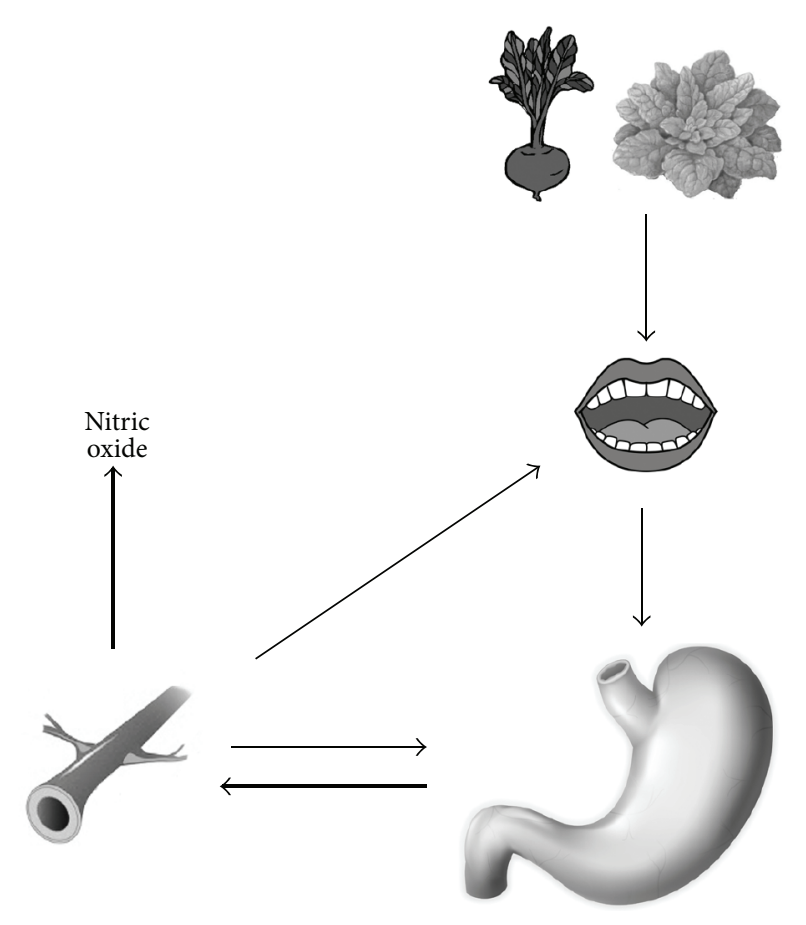

FIgURE 1: Nitrate (thin arrows) intake from the diet is swallowed and completely absorbed in the upper gastrointestinal tract. About $25 \%$ of this amount is concentrated in the salivary glands and still inside the mouth is reduced to nitrite by anaerobic bacteria present on the tongue and is swallowed again. In the stomach, nitrite acid undergoes reduction and is converted to NO (thick arrows) that has vasodilatory action on blood vessels.

dose per day may be sufficient to achieve benefits in lowering BP $[50,51]$.

\section{Conclusion}

Increasing nitrite levels by nitrate intake appears to have beneficial effects in many physiologic and clinical settings. Several clinical trials are being conducted to determine the great therapeutic potential of increasing the bioavailability of nitrite in human health and disease, including studies related to vascular aging. Nevertheless, there are many limitations in nitrate studies, such as the type of population enrolled in each trial and the dependent effect of the baseline BP. Therefore, the effects are unlikely to be the same among healthy and hypertensive individuals. In addition, when evaluating treated hypertensive patients, use of medications, such as calcium channel antagonists, may affect endothelial function and hence can interfere in some vascular parameters. Sample size is also a limiting factor considering the fact that it is small in most of nitrate studies. Indeed, large clinical trials are necessary to confirm the potential beneficial effects of inorganic nitrate in patients with CVD. Even with these considerations, dietary nitrate seems to represent an inexpensive and a promising complementary therapy to support hypertension treatment with benefits for cardiovascular health. 
TABLE 2: Clinical trials evaluating the effects of dietary inorganic nitrate on cardiovascular health.

\begin{tabular}{|c|c|c|c|c|c|c|}
\hline Population & $\begin{array}{l}\text { Study design } \\
\text { and duration }\end{array}$ & Nitrate dose & Control & $\begin{array}{l}\text { Vascular } \\
\text { parameter }\end{array}$ & Result & Reference \\
\hline $\begin{array}{l}\text { Hypertensive } \\
n=68 \\
57 \text { years } \\
144 / 88 \mathrm{mmHg}\end{array}$ & $\begin{array}{l}\text { Chronic } \\
4 \text { weeks }\end{array}$ & $\begin{array}{c}450 \mathrm{mg} \\
(250 \mathrm{~mL} \text { beetroot juice })\end{array}$ & $\begin{array}{l}\text { Beetroot juice } \\
\text { poor in nitrate }\end{array}$ & $\begin{array}{l}\text { PWV } \\
\text { FMD } \\
\text { SBP } \\
\text { DBP }\end{array}$ & $\begin{array}{c}\downarrow \mathrm{PWV}, \uparrow \mathrm{FMD} \\
\downarrow \mathrm{SBP}, \downarrow \mathrm{DBP} \\
\downarrow \mathrm{SBP}_{24 \mathrm{~h}} \\
\downarrow \mathrm{DBP}_{24 \mathrm{~h}}\end{array}$ & Kapil et al., 2015 [12] \\
\hline $\begin{array}{l}\text { Hypertensive } \\
n=27 \\
63 \text { years } \\
133 / 77 \mathrm{mmHg}\end{array}$ & $\begin{array}{l}\text { Chronic } \\
1 \text { week }\end{array}$ & $\begin{array}{c}420 \mathrm{mg} \\
(140 \mathrm{~mL} \text { beetroot juice })\end{array}$ & $\begin{array}{l}\text { Beetroot juice } \\
\text { poor in nitrate }\end{array}$ & $\begin{array}{l}\text { SBP } \\
\text { DBP }\end{array}$ & No effect & Bondonno et al., 2015 [13] \\
\hline $\begin{array}{l}\text { Overweight } \\
\text { elderly } \\
n=24 \\
63 \text { years } \\
\end{array}$ & $\begin{array}{l}\text { Chronic } \\
3 \text { weeks }\end{array}$ & $\begin{array}{c} \pm 350 \mathrm{mg} \\
(70 \mathrm{~mL} \text { beetroot juice })\end{array}$ & $\begin{array}{l}\text { Blackcurrant } \\
\text { juice }\end{array}$ & $\begin{array}{l}\text { SBP } \\
\text { DBP }\end{array}$ & $\begin{array}{c}\downarrow \text { SBP } \\
\text { No effect on DBP }\end{array}$ & Jajja et al., 2014 [14] \\
\hline $\begin{array}{l}\text { T2DM } \\
n=27 \\
67 \text { years } \\
143 / 81 \mathrm{mmHg} \\
\end{array}$ & $\begin{array}{l}\text { Chronic } \\
2 \text { weeks }\end{array}$ & $\begin{array}{c}500 \mathrm{mg} \\
(250 \mathrm{~mL} \text { beetroot juice })\end{array}$ & $\begin{array}{l}\text { Beetroot juice } \\
\text { poor in nitrate }\end{array}$ & FMD & No effect & Gilchrist et al., 2013 [15] \\
\hline $\begin{array}{l}\text { Healthy } \\
n=30 \\
47 \text { years } \\
112 / 68 \mathrm{mmHg}\end{array}$ & $\begin{array}{l}\text { Acute } \\
0-2 \mathrm{~h}\end{array}$ & $\begin{array}{c}190 \mathrm{mg} \\
(200 \mathrm{~g} \text { spinach })\end{array}$ & Rice milk & FMD & $2 \% \uparrow$ after $2 \mathrm{~h}$ & Bondonno et al., 2012 [16] \\
\hline $\begin{array}{l}\text { Healthy } \\
n=9 \\
25 \text { years } \\
121 / 71 \mathrm{mmHg}\end{array}$ & $\begin{array}{l}\text { Acute } \\
0-3 \mathrm{~h}\end{array}$ & $\begin{array}{c}375 \mathrm{mg} \\
(250 \mathrm{~mL} \text { beetroot juice })\end{array}$ & Mineral water & $\begin{array}{l}\text { SBP } \\
\text { DBP }\end{array}$ & $\begin{array}{c}\downarrow \text { SBP after } 3 \mathrm{~h} \\
\text { No effect on DBP }\end{array}$ & Kapil et al., 2010 [17] \\
\hline $\begin{array}{l}\text { Healthy } \\
n=14 \\
26 \text { years } \\
106 / 70 \mathrm{mmHg}\end{array}$ & $\begin{array}{c}\text { Acute } \\
0-6 \mathrm{~h}-24 \mathrm{~h}\end{array}$ & $\begin{array}{c}1437 \mathrm{mg} \\
(500 \mathrm{~mL} \text { beetroot juice })\end{array}$ & Mineral water & $\begin{array}{l}\text { SBP } \\
\text { DBP } \\
\text { MAP }\end{array}$ & $\begin{array}{l}\downarrow \mathrm{SBP} \\
\downarrow \mathrm{DBP} \\
\downarrow \mathrm{MAP}\end{array}$ & Webb et al., 2008 [18] \\
\hline $\begin{array}{l}\text { Healthy } \\
n=10 \\
27 \text { years }\end{array}$ & $\begin{array}{l}\text { Acute } \\
0-2 \mathrm{~h}\end{array}$ & $\begin{array}{c}1437 \mathrm{mg} \\
(500 \mathrm{~mL} \text { beetroot juice) }\end{array}$ & Mineral water & FMD & $\begin{array}{l}\text { Protection against } \\
\text { reperfusion } \\
\text { ischemia after } 2 \mathrm{~h}\end{array}$ & Webb et al., 2008 [18] \\
\hline
\end{tabular}

T2DM, type 2 diabetes mellitus; PWV, pulse wave velocity; FMD, flow mediated dilation; SBP, systolic blood pressure; DBP, diastolic blood pressure; MAP, mean arterial pressure.

\section{Competing Interests}

The authors declare that they have no competing interests.

\section{References}

[1] P. A. James, S. Oparil, B. L. Carter et al., "2014 Evidence-based guideline for the management of high blood pressure in adults: report from the panel members appointed to the Eighth Joint National Committee (JNC 8)," The Journal of the American Medical Association, vol. 311, no. 5, pp. 507-520, 2014.

[2] M. Pereira, N. Lunet, A. Azevedo, and H. Barros, "Differences in prevalence, awareness, treatment and control of hypertension between developing and developed countries," Journal of Hypertension, vol. 27, no. 5, pp. 963-975, 2009.

[3] C. Lenfant, A. V. Chobanian, D. W. Jones, and E. J. Roccella, "Seventh report of the Joint National Committee on the Prevention, Detection, Evaluation, and Treatment of High Blood Pressure (JNC 7): resetting the hypertension sails," Hypertension, vol. 41, no. 6, pp. 1178-1179, 2003.

[4] F. Contreras, M. Rivera, J. Vásquez, M. A. De La Parte, and M. Velasco, "Endothelial dysfunction in arterial hypertension,"
Journal of Human Hypertension, vol. 14, supplement 1, pp. S20S25, 2000.

[5] J. E. Deanfield, J. P. Halcox, and T. J. Rabelink, "Endothelial function and dysfunction: testing and clinical relevance," Circulation, vol. 115, no. 10, pp. 1285-1295, 2007.

[6] H. Cai and D. G. Harrison, "Endothelial dysfunction in cardiovascular diseases: the role of oxidant stress," Circulation Research, vol. 87, no. 10, pp. 840-844, 2000.

[7] J. D. Rossen, Y. Agmon, R. Gorlin, E. C. Abbott, K. Egashira, and A. Takeshita, "Endothelial dysfunction in microvascular angina," The New England Journal of Medicine, vol. 329, no. 23, pp. 1739-1740, 1993.

[8] P. O. Bonetti, G. M. Pumper, S. T. Higano, D. R. Holmes Jr., J. T. Kuvin, and A. Lerman, "Noninvasive identification of patients with early coronary atherosclerosis by assessment of digital reactive hyperemia," Journal of the American College of Cardiology, vol. 44, no. 11, pp. 2137-2141, 2004.

[9] D. A. Hobbs, T. W. George, and J. A. Lovegrove, "The effects of dietary nitrate on blood pressure and endothelial function: a review of human intervention studies," Nutrition Research Reviews, vol. 26, no. 2, pp. 210-222, 2013. 
[10] B. McNally, J. L. Griffin, and L. D. Roberts, "Dietary inorganic nitrate: from villain to hero in metabolic disease?" Molecular Nutrition \& Food Research, vol. 60, no. 1, pp. 67-78, 2016.

[11] A. H. Gorenjak and A. Cencič, "Nitrate in vegetables and their impact on human health. A review," Acta Alimentaria, vol. 42, no. 2, pp. 158-172, 2013.

[12] V. Kapil, R. S. Khambata, A. Robertson, M. J. Caulfield, and A. Ahluwalia, "Dietary nitrate provides sustained blood pressure lowering in hypertensive patients: a randomized, phase 2, double-blind, placebo-controlled study," Hypertension, vol. 65, no. 2, pp. 320-327, 2015.

[13] C. P. Bondonno, A. H. Liu, K. D. Croft et al., "Absence of an effect of high nitrate intake from beetroot juice on blood pressure in treated hypertensive individuals: a randomized controlled trial," The American Journal of Clinical Nutrition, vol. 102, no. 2, pp. 368-375, 2015.

[14] A. Jajja, A. Sutyarjoko, J. Lara et al., "Beetroot supplementation lowers daily systolic blood pressure in older, overweight subjects," Nutrition Research, vol. 34, no. 10, pp. 868-875, 2014.

[15] M. Gilchrist, P. G. Winyard, K. Aizawa, C. Anning, A. Shore, and N. Benjamin, "Effect of dietary nitrate on blood pressure, endothelial function, and insulin sensitivity in type 2 diabetes," Free Radical Biology and Medicine, vol. 60, pp. 89-97, 2013.

[16] C. P. Bondonno, K. D. Croft, I. B. Puddey et al., "Nitrate causes a dose-dependent augmentation of nitric oxide status in healthy women," Food and Function, vol. 3, no. 5, pp. 522-527, 2012.

[17] V. Kapil, A. J. Webb, and A. Ahluwalia, "Inorganic nitrate and the cardiovascular system," Heart, vol. 96, no. 21, pp. 1703-1709, 2010.

[18] A. J. Webb, N. Patel, S. Loukogeorgakis et al., "Acute blood pressure lowering, vasoprotective, and antiplatelet properties of dietary nitrate via bioconversion to nitrite," Hypertension, vol. 51, no. 3, pp. 784-790, 2008.

[19] P. L. Huang, "A comprehensive definition for metabolic syndrome," Disease Models and Mechanisms, vol. 2, no. 5-6, pp. 231237, 2009.

[20] R. H. Eckel, S. M. Grundy, and P. Z. Zimmet, "The metabolic syndrome," The Lancet, vol. 365, no. 9468, pp. 1415-1428, 2005.

[21] L. D. Monti, C. Barlassina, L. Citterio et al., "Endothelial nitric oxide synthase polymorphisms are associated with type 2 diabetes and the insulin resistance syndrome," Diabetes, vol. 52, no. 5, pp. 1270-1275, 2003.

[22] P. L. Huang, "eNOS, metabolic syndrome and cardiovascular disease," Trends in Endocrinology and Metabolism, vol. 20, no. 6, pp. 295-302, 2009.

[23] M. Carlström, F. J. Larsen, T. Nyström et al., "Dietary inorganic nitrate reverses features of metabolic syndrome in endothelial nitric oxide synthase-deficient mice," Proceedings of the National Academy of Sciences of the United States of America, vol. 107, no. 41, pp. 17716-17720, 2010.

[24] M. Siervo, S. J. Jackson, and L. J. C. Bluck, "In-vivo nitric oxide synthesis is reduced in obese patients with metabolic syndrome: application of a novel stable isotopic method," Journal of Hypertension, vol. 29, no. 8, pp. 1515-1527, 2011.

[25] L. Van Horn, M. McCoin, P. M. Kris-Etherton et al., "The evidence for dietary prevention and treatment of cardiovascular disease," Journal of the American Dietetic Association, vol. 108, no. 2, pp. 287-331, 2008.

[26] V. Savica, G. Bellinghieri, and J. D. Kopple, "The effect of nutrition on blood pressure," Annual Review of Nutrition, vol. 30, pp. 365-401, 2010.
[27] L. A. Bazzano, J. He, L. G. Ogden et al., "Fruit and vegetable intake and risk of cardiovascular disease in US adults: the first National Health and Nutrition Examination Survey Epidemiologic Follow-up study," American Journal of Clinical Nutrition, vol. 76, no. 1, pp. 93-99, 2002.

[28] K. J. Joshipura, F. B. Hu, J. E. Manson et al., "The effect of fruit and vegetable intake on risk for coronary heart disease," Annals of Internal Medicine, vol. 134, no. 12, pp. 1106-1114, 2001.

[29] E. R. Miller III, T. P. Erlinger, and L. J. Appel, “The effects of macronutrients on blood pressure and lipids: an overview of the DASH and OmniHeart trials," Current Atherosclerosis Reports, vol. 8, no. 6, pp. 460-465, 2006.

[30] L. J. Appel, M. W. Brands, S. R. Daniels, N. Karanja, P. J. Elmer, and F. M. Sacks, "Dietary approaches to prevent and treat hypertension: a scientific statement from the American Heart Association," Hypertension, vol. 47, no. 2, pp. 296-308, 2006.

[31] T. J. Moore, P. R. Conlin, J. Ard, and L. P. Svetkey, "DASH (Dietary Approaches to Stop Hypertension) diet is effective treatment for stage 1 isolated systolic hypertension," Hypertension, vol. 38, no. 2, pp. 155-158, 2001.

[32] N. G. Hord, Y. Tang, and N. S. Bryan, "Food sources of nitrates and nitrites: the physiologic context for potential health benefits," The American Journal of Clinical Nutrition, vol. 90, no. 1, pp. 1-10, 2009.

[33] M. Siervo, J. Lara, I. Ogbonmwan, and J. C. Mathers, "Inorganic nitrate and beetroot juice supplementation reduces blood pressure in adults: a systematic review and meta-analysis," Journal of Nutrition, vol. 143, no. 6, pp. 818-826, 2013.

[34] S. S. Mirvish, "Role of N-nitroso compounds (NOC) and Nnitrosation in etiology of gastric, esophageal, nasopharyngeal and bladder cancer and contribution to cancer of known exposures to NOC," Cancer Letters, vol. 93, no. 1, pp. 17-48, 1995.

[35] T. T. Mensinga, G. J. A. Speijers, and J. Meulenbelt, "Health implications of exposure to environmental nitrogenous compounds," Toxicological Reviews, vol. 22, no. 1, pp. 41-51, 2003.

[36] A. G. van Velzen, A. J. A. M. Sips, R. C. Schothorst, A. C. Lambers, and J. Meulenbelt, "The oral bioavailability of nitrate from nitrate-rich vegetables in humans," Toxicology Letters, vol. 181, no. 3, pp. 177-181, 2008.

[37] M. B. Katan, "Nitrate in foods: harmful or healthy?" American Journal of Clinical Nutrition, vol. 90, no. 1, pp. 11-12, 2009.

[38] P. Terry, J. B. Terry, and A. Wolk, "Fruit and vegetable consumption in the prevention of cancer: an update," Journal of Internal Medicine, vol. 250, no. 4, pp. 280-290, 2001.

[39] S. R. Tannenbaum, M. Weisman, and D. Fett, "The effect of nitrate intake on nitrite formation in human saliva," Food and Cosmetics Toxicology, vol. 14, no. 6, pp. 549-552, 1976.

[40] J. O. Lundberg, E. Weitzberg, J. A. Cole, and N. Benjamin, "Nitrate, bacteria and human health," Nature Reviews Microbiology, vol. 2, no. 7, pp. 593-602, 2004.

[41] D. A. Hobbs, M. G. Goulding, A. Nguyen et al., "Acute ingestion of beetroot bread increases endothelium-independent vasodilation and lowers diastolic blood pressure in healthymen: a randomized controlled trial," Journal of Nutrition, vol. 143, no. 9, pp. 1399-1405, 2013.

[42] X. Gao, T. Yang, M. Liu et al., "NADPH oxidase in the renal microvasculature is a primary target for blood pressurelowering effects by inorganic nitrate and nitrite," Hypertension, vol. 65, no. 1, pp. 161-170, 2015.

[43] M. P. Hezel, M. Liu, T. A. Schiffer et al., "Effects of long-term dietary nitrate supplementation in mice," Redox Biology, vol. 5, pp. 234-242, 2015. 
[44] A. H. Liu, C. P. Bondonno, K. D. Croft et al., "Effects of a nitraterich meal on arterial stiffness and blood pressure in healthy volunteers," Nitric Oxide, vol. 35, pp. 123-130, 2013.

[45] M. Govoni, E. Å. Jansson, E. Weitzberg, and J. O. Lundberg, "The increase in plasma nitrite after a dietary nitrate load is markedly attenuated by an antibacterial mouthwash," Nitric Oxide, vol. 19, no. 4, pp. 333-337, 2008.

[46] E. Å. Jansson, L. Huang, R. Malkey et al., "A mammalian functional nitrate reductase that regulates nitrite and nitric oxide homeostasis," Nature Chemical Biology, vol. 4, no. 7, pp. 411-417, 2008.

[47] V. Kapil, A. B. Milsom, M. Okorie et al., "Inorganic nitrate supplementation lowers blood pressure in humans: role for nitrite-derived no," Hypertension, vol. 56, no. 2, pp. 274-281, 2010.

[48] D. A. Hobbs, N. Kaffa, T. W. George, L. Methven, and J. A. Lovegrove, "Blood pressure-lowering effects of beetroot juice and novel beetroot-enriched bread products in normotensive male subjects," British Journal of Nutrition, vol. 108, no. 11, pp. 2066-2074, 2012.

[49] F. J. Larsen, B. Ekblom, K. Sahlin, J. O. Lundberg, and E. Weitzberg, "Effects of dietary nitrate on blood pressure in healthy volunteers," The New England Journal of Medicine, vol. 355, no. 26, pp. 2792-2793, 2006.

[50] V. Kapil, E. Weitzberg, J. O. Lundberg, and A. Ahluwalia, "Clinical evidence demonstrating the utility of inorganic nitrate in cardiovascular health," Nitric Oxide-Biology and Chemistry, vol. 38, no. 1, pp. 45-57, 2014.

[51] M. R. Law, J. K. Morris, and N. J. Wald, "Use of blood pressure lowering drugs in the prevention of cardiovascular disease: meta-analysis of 147 randomised trials in the context of expectations from prospective epidemiological studies," The British Medical Journal, vol. 338, no. 7705, p. 1245, 2009. 


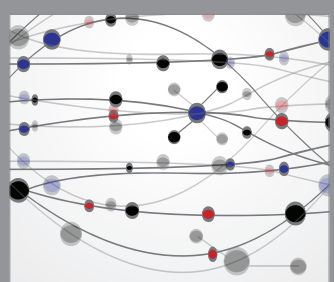

The Scientific World Journal
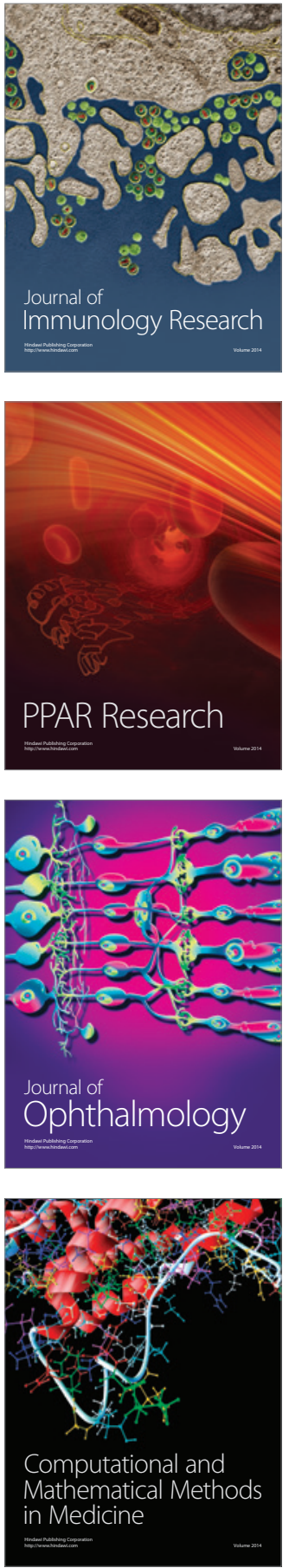

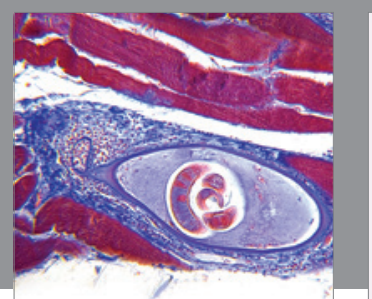

Gastroenterology Research and Practice

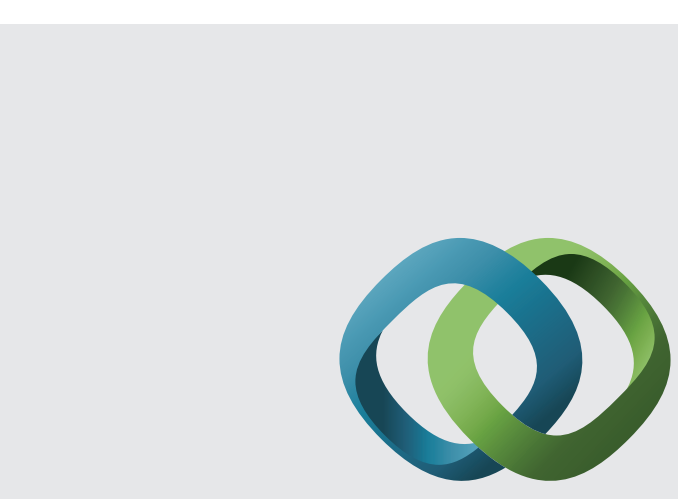

\section{Hindawi}

Submit your manuscripts at

http://www.hindawi.com
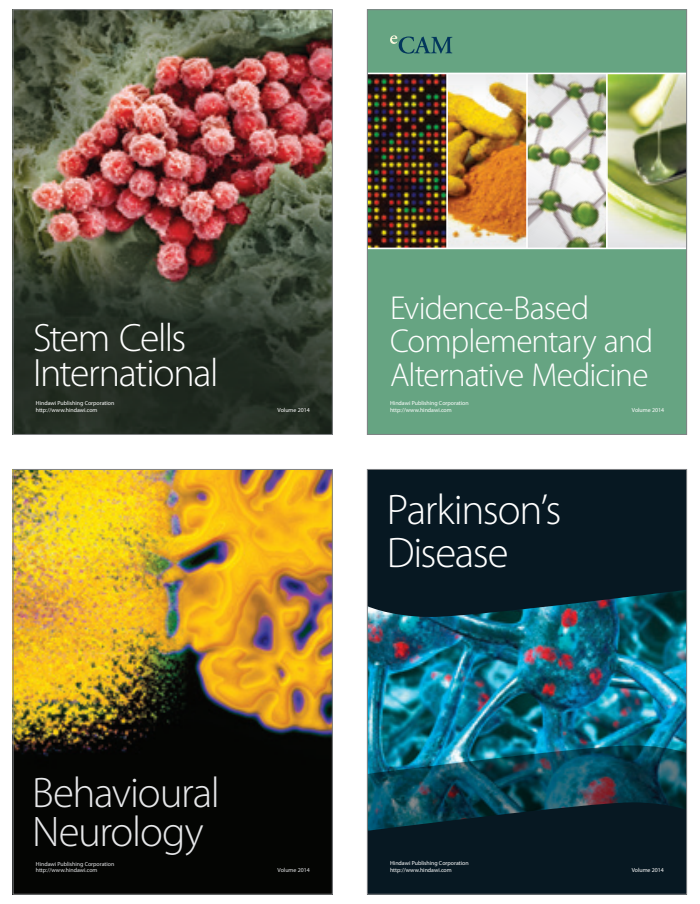
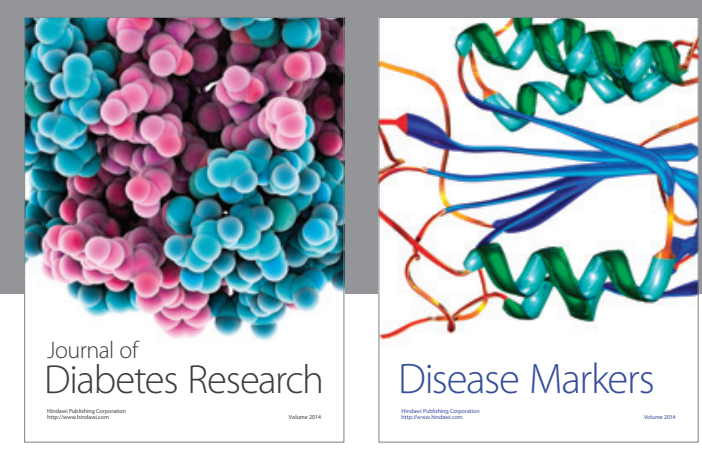

Disease Markers
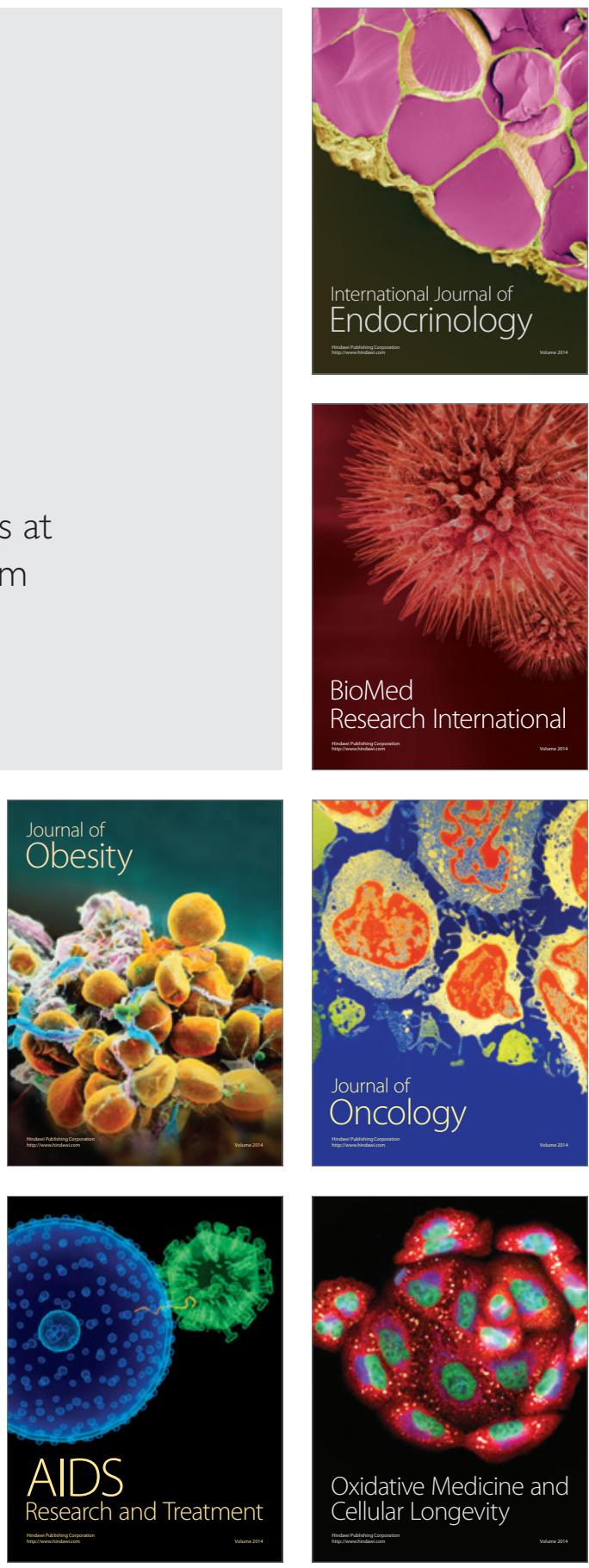